\title{
EXTENSIVE CRANIOFACIAL INJURY CAUSED BY CIRCULAR SAW
}

Contributions: A Study design/planning B Data collection/entry C Data analysis/statistics D Data interpretation D Data interpretation E Preparation of manuscript F Literature analysis/search $\mathrm{G}$ Funds collection

\section{Krzysztof Kuśmierczyk ${ }^{\mathrm{E}}$, Anna Jałocha-Kaczka, Magdalena Wactawek ${ }^{B}$, Marzena Mielczarek ${ }^{C}$, Jurek Olszewski ${ }^{A}$}

Department of Otolaryngology, Laryngological Oncology, Audiology and Phoniatrics, Medical University of Lodz, Poland

Corresponding author: Prof. Jurek Olszewski, $\mathrm{MD}, \mathrm{PhD}$, Department of Otolaryngology and Laryngological Oncology, Audiology and Phoniatrics, Medical University of Łódź, Żeromskiego 113, 90-549 Łódź, Poland, e-mail: jurek.olszewski@umed.lodz.pl

\section{Abstract}

Introduction: Craniofacial injuries are a complex clinical issue and their treatment requires multi-specialty intervention. We present the case of a man hospitalized at the Department of Otolaryngology, Laryngological Oncology, Audiology and Phoniatrics, Medical University in Lodz, Poland, due to extensive craniofacial injury caused by a circular saw.

Case report: A 61-year-old male patient (Z.K.) was transported by ambulance to the Emergency Department of the University Clinical Hospital, Military Memorial Medical Academy, Lodz, due to extensive craniofacial injury. The patient was conscious and remembered the course of the event. He exhibited stable respiratory and cardiovascular function and was in logical verbal contact. A CT scan revealed fracture of the anterior wall of the frontal sinus, with dislocation of fragments to the area of the piriform aperture on the right side, and a hematoma in the right frontal and maxillary sinus. The diagnostic and therapeutic management was successful, with the patient discharged from hospital on the 9th day in good general condition. The external appearance after treatment was fully satisfactory for the patient. There were no inflammatory complications in the healing of wounds and no evidence of lagophthalmos, facial nerve paresis, ocular complications, or excessive lacrimation which could result of nosolacrimal duct obstruction. The success of the therapy, both functionally and aesthetically, was achieved due to quick diagnosis and appropriate surgical and pharmacological treatment, including broad-spectrum antibiotics.

Conclusions: In the case of extensive craniofacial injuries, rapid diagnosis and implementation of appropriate, highly specialized multidisciplinary treatment is needed. Patients such as this should be referred to the highest level centers.

Key words: extensive injury $\bullet$ facial part of the skull

\section{LESIÓN EXTENSA CRANEOFACIAL CAUSADA POR UNA SIERRA CIRCULAR}

\section{Resumen}

Introducción: Las lesiones craneofaciales son un problema clínico complejo y su tratamiento requiere una intervención multidisciplinaria. El objetivo del estudio fue presentar un caso de un hombre de 61 años hospitalizado en la Clínica de Otorrinolaringología, Oncología laringológica, Audiología y Foniatría de la Universidad de Medicina de Łódź debido a una lesión extensa craneofacial causada por una sierra circular.

Descripción del caso: un paciente de 61 años (Z.K.) fue trasladado por el equipo de Servicio de Emergencias Médicas al servicio de emergencias del Hospital Clínico Universitario de la Academia Médica Militar de la Universidad de Medicina de Łódź debido a lesiones craneofaciales extensas. El paciente estaba consciente y recordaba el curso de todo el evento. Presentaba una capacidad respiratoria y circulatoria preservada y mantenía un contacto verbal lógico. La tomografía computarizada mostró: fractura de la pared del seno frontal con desplazamiento de fragmentos en el área de la apertura piriforme del lado derecho junto a hematoma en el seno frontal y el seno maxilar derecho. Los procedimientos diagnósticos y terapéuticos demostraron ser efectivos en este caso. El paciente fue dado de alta del hospital el noveno día con un buen estado general. La apariencia externa después del tratamiento era totalmente satisfactoria para el paciente. Durante la hospitalización, no hubo complicaciones asociadas con la curación de las heridas postraumáticas. No hubo signos de exoftalmia, paresia del nervio facial, complicaciones orbitales ni lagrimeo excesivo causado por una obstrucción del canal nasal-lagrimal. El éxito terapéutico, tanto funcional como estético, se ha logrado gracias al diagnóstico rápido y al tratamiento quirúrgico y farmacológico adecuado, incluida una terapia con antibióticos de amplio espectro.

Conclusiones: En los casos de lesiones craneofaciales extensas, el diagnóstico rápido y la implementación de un tratamiento interdisciplinario multidisciplinario apropiado desempeñan un papel clave. Por lo tanto, los pacientes como los descritos anteriormente deben dirigirse a los centros médicos con la mayor diligencia posible.

Palabras clave: lesiones extensas • craneofacial • sierra circular.

\section{ОБШИРНЫЕ ЧЕРЕПНО-ЛИЦЕВЫЕ ТРАВМЫ, НАНЕСЕННЫЕ ЦЕРКУЛЯРНОЙ ПИЛОЙ}

\section{Аннотация}

Введение: Черепно-лицевые травмы представляют собой сложную клиническую проблему, и их лечение требует междисциплинарного вмешательства. Целью исследования является анализ случая 61-летнего мужчины, госпитализированного в 
Отделение отоларингологии, ларингологической онкологии, аудиологии и фониатрии Медицинского университета в Лодзи в связи с обширным черепно-лицевой травмой, нанесенной церкулярной пилой.

Описание случая: 61-летний пациент (3.К.) был доставлен бригадой скорой помощи в Отделение неотложной помощи Университетской клинической больницы Военно-медицинской академии Медицинского университета в Лодзи в связи с обширными черепно-лицевыми травмами. Пациент был в сознании и мог восстановить произошедшее. Дыхательные функции и кровообращение были удовлетворительны, пациент был в сознании, речь логична. Компьютерная томография показала перелом передней стенки лобной пазухи со смещением отломков в область грушевидного отверстия с правой стороны и гематому в правой лобной и верхнечелюстной пазухах. Диагностические и терапевтические процедуры оказались эффективными в данном случае. Пациент был выписан из больницы на 9 сутки в хорошем общем состоянии. Внешний вид после операции был полностью удовлетворительным для пациента. Во время госпитализации не появилось никаких воспалительных осложнений, связанных с заживлением посттравматических ран. Также не наблюдалось признаков экзофтальма, пареза лицевого нерва, орбитальных осложнений или чрезмерного слезотечения, вызванного обструкцией носо-слезного канала. Терапевтический эффект, как функциональный, так и эстетический, был достигнут благодаря быстрой диагностике и соответствующему хирургическому и фармакологическому лечению, включая антибиотикотерапию широкого спектра действия.

Выводы: В случае обширной черепно-лицевой травмы быстрая диагностика и проведение надлежащего междисциплинарного лечения играют ключевую роль. Следовательно, следует направлять пациентов, подобных описанным выше, в высокоспециализированные центры.

Ключевые слова: обширные травмы • черепно-лицевая область • церкулярная пила

\section{ROZLEGŁE OBRAŻENIA TWARZOCZASZKI SPOWODOWANE PRZEZ PIŁĘ TARCZOWĄ}

\section{Streszczenie}

Wstęp: Urazy twarzoczaszki stanowią złożony problemem kliniczny a ich leczenie wymaga wielospecjalistycznej interwencji. Celem pracy było przedstawienie przypadku 61-letniego mężczyzny hospitalizowanego w Klinice Otolaryngologii, Onkologii Laryngologicznej, Audiologii i Foniatrii Uniwersytetu Medycznego w Łodzi z powodu rozległych obrażeń twarzoczaszki spowodowanych piłą tarczową.

Opis przypadku: 61-letni pacjent (Z.K.) został przewieziony przez Zespół Pogotowia Ratunkowego do Oddziału Ratunkowego Uniwersyteckiego Szpitala Klinicznego im. Wojskowej Akademii Medycznej Uniwersytetu Medycznego w Łodzi z powodu rozległych obrażeń twarzoczaszki. Pacjent był przytomny i pamiętał przebieg całego zdarzenia. Był wydolny oddechowo i krążeniową w zachowanym kontakcie słowno-logicznym. Tomografia komputerowa wykazała: złamanie przedniej ściany zatoki czołowej z przemieszczeniem odłamów w okolicę otworu gruszkowatego po stronie prawej oraz krwiaka w prawej zatoce czołowej i szczękowej. Postępowanie diagnostyczne i terapeutyczne okazało się w tym przypadku skuteczne. Pacjent został wypisany ze szpitala w 9 dobie w stanie ogólnym dobrym. Wygląd zewnętrzny po zabiegu był dla pacjenta w pełni satysfakcjonujący. W trakcie hospitalizacji nie wystąpiły powikłania zapalne związane z gojeniem się ran pourazowych. Nie zaobserwowano także objawów wytrzeszczu, niedowładu nerwu twarzowego, powikłań oczodołowych lub nadmiernego łzawienia spowodowanego niedrożnością kanału nosowo-łzowego. Sukces terapeutyczny, zarówno funkcjonalny jak i estetyczny, osiagnięto dzięki szybkiej diagnostyce oraz odpowiedniemu leczeniu chirurgicznemu i farmakologicznemu, w tym antybiotykoterapii szerokowidomowej.

Wnioski: W przypadkach rozległych obrażeń twarzoczaszki kluczową rolę odgrywa szybka diagnostyka oraz wdrożenie odpowiedniego, wielospecjalistycznego leczenia interdyscyplinarnego. W związku z powyższym, pacjenci tacy jak opisany powyżej powinni być kierowani do ośrodków o najwyższym stopniu referencyjności.

Słowa kluczowe: rozległe obrażenia • twarzoczaszka •, piła tarczowa

\section{Introduction}

Craniofacial injuries can occur as an isolated injury or involve multiple injuries. Frequently they present a serious, interdisciplinary medical problem. In order to establish the correct diagnosis and implement appropriate treatment, they often require the cooperation of many specialists. Based on literature data, it has been estimated that craniofacial injuries are most common in subjects aged 18 to 30 years $[1,2]$ and that males sustain them more frequently than females [1-5].

The work of Zielińska-Bliźniewska et al. [1] gave an analysis of patients with craniomaxillofacial injuries treated at the Department of Otolaryngology, Laryngological Oncology, Audiology and Phoniatrics, Lodz, Poland, in 2009-11. Their analysis showed that the most common causes of craniomaxillofacial injuries were traffic accidents (39.3\%), assaults $(25.6 \%)$, falls $(20.6 \%)$, accidents at work (11.5\%), and during sports activities (3.0\%) [1]. Cases of severe craniofacial injuries caused by rotary tools, including saws, also form a part of the published literature $[6,7]$.

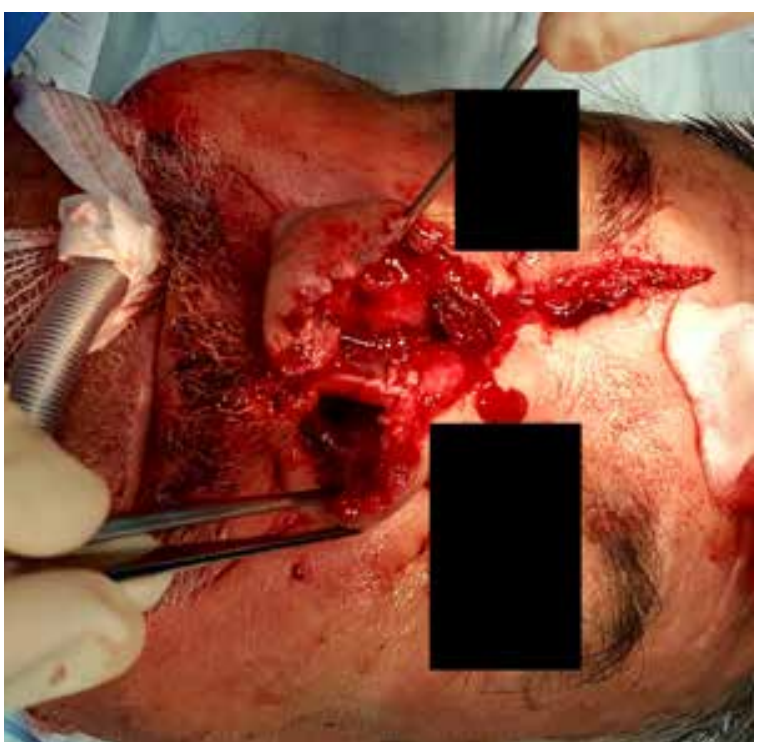

Fig. 1. Extensive craniofacial wound in a 61-year-old man. 
The growth of industrialization and mechanization in today's world contributes greatly to the incidence of injuries. Some authors have emphasized that the types of injuries, their number, and frequency depend on the microregion where they occur [8]. Craniofacial injuries can involve soft tissue wounds, bone fractures, or penetration of fragments or entire foreign bodies into the skin, muscles, bone, paranasal sinuses, or orbit [9-12]. Often the injuries are so severe they are life-threatening and require urgent medical intervention. Craniofacial injuries are an increasing clinical problem, requiring both diagnostic and therapeutic input and often requiring multi-specialist management.

This study presents a patient with extensive craniofacial injury caused by a circular saw.

\section{Case Report}

Due to extensive craniofacial injury (Fig. 1), a 61-yearold male patient (Z.K.) was transported by ambulance to the Emergency Department of the University Clinical Hospital, Military Memorial Medical Academy, in Lodz. The patient was conscious and remembered the course of the event. He exhibited stable respiratory and cardiovascular function and was in logical verbal contact. While he was cutting a tree, the circular saw fell out of his hands, damaging the facial skeleton from the glabella through the nasal dorsum down to the upper lip and also injuring part of the right ankle. Blood tests and diagnostic examinations were performed in the Emergency Department.

A CT scan of the head revealed fracture of the anterior wall of the right frontal sinus and fracture of the right orbital bone with a small hematoma in the lumen of the right frontal sinus (Bogdan Błaszczyk, MD, PhD, Department of Radiological and Isotopic Diagnostics and Therapy, Medical University in Lodz). From a CT of the facial skeleton (Figs 2 and 3), the fracture gap was found to run on the right side from the orbital part of the frontal bone (anterior wall of the right frontal sinus), through the supraorbital margin and the frontal process of the right maxilla,

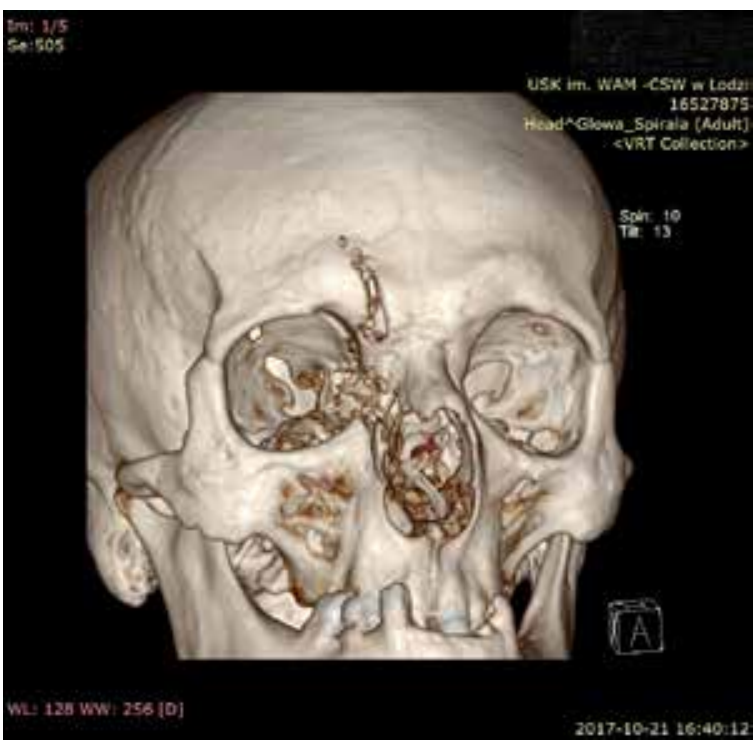

Fig. 2. 3D computed tomography image of craniofacial injuries in the patient. with fragmentation and dislocation from the side of the bone lamella to the right edge of the piriform aperture. These changes were accompanied by a large hematoma and soft-tissue edema of the right nasal and orbital region with small air bubbles and hematoma in the right frontal and right maxillary sinus (Dr Bogdan Błaszczyk).

After the laryngological consultation, and due to severe bleeding and the threat to health and life, the patient was admitted as an emergency case to the Department of Otolaryngology, Laryngological Oncology, Audiology and Phoniatrics and prepared for surgery under endotracheal general anesthesia. After preparation of the surgical site, the bleeding vessels were coagulated on the right side of the glabellar area and the external nose, which was fragmented into two parts as a result of the injury. Bleeding and a torn lower right nasal concha were surgically repaired. Nasal packing of latex glove fingers was used to provide support. A wound revision was performed in the glabellar area and a linear scar was found in the anterior wall of the right frontal sinus (about $2.0 \times 0.5 \mathrm{~cm}$ ). Layer-suturing was applied in the glabellar area and external nose, reconstructing the nasal pyramid. The patient tolerated the procedure well. Due to extensive injuries and the disruption of bone tissue continuity, antibiotics (biofuroxime $750 \mathrm{mg}$ three times a day and clindamycin $300 \mathrm{mg}$ three times a day) were administered. Anti-tetanus prophylaxis was administered.

The patient also underwent an orthopedic consultation revealing a $3-\mathrm{cm}$ long wound located on the anterior surface of the right ankle that was surgically repaired. An $\mathrm{X}$-ray examination detected neither post-traumatic anomalies nor foreign bodies.

On the first day after surgery, the patient was in good condition - the wound showing normal healing. However, eyelid edema was observed, more on the right side. For this reason, the patient was given an ophthalmological consultation. This revealed even pupils correctly responding to light, but massive edema of the eyelids and soft tissues

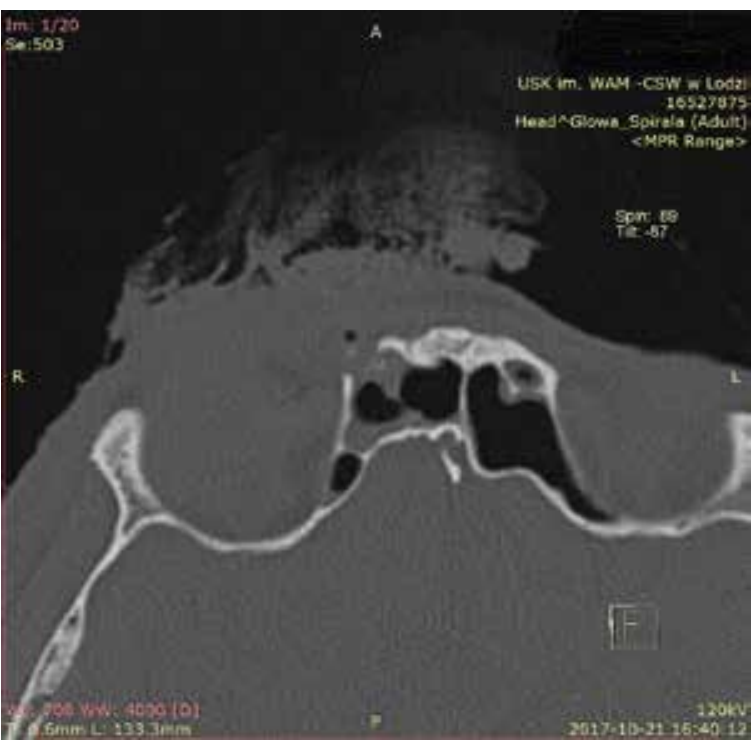

Fig. 3. CT scan of the patient with visible defect in the anterior wall of the frontal sinus. 


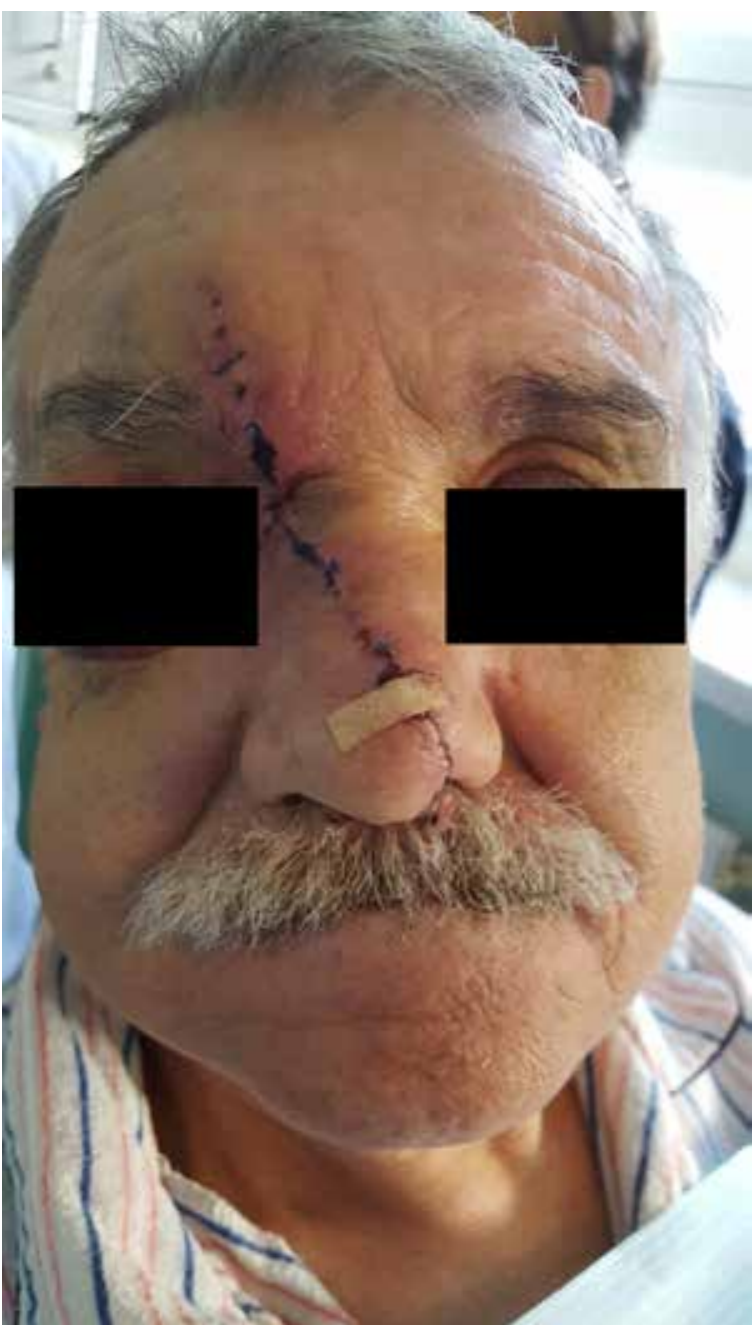

Fig. 4. Craniofacial soft tissues before suture removal.

of the right frontal area with periorbital ecchymosis. Motility of the eyeballs was preserved. The right eye showed conjunctival chemosis but no other significant deviations. The fundus of the eye in the ophthalmoscopic examination was found to be without posttraumatic change (Natalia Skuza, MD, Department of Ophthalmology and Visual Rehabilitation, Medical University in Lodz). Dicortineff was applied to the conjunctiva of the right eye. However, the edema increased on the second day, so the local condition was analyzed and after consultation with the Head of the Department a drain was inserted into the right frontal sinus. The bilateral nasal packing was also removed with no bleeding observed. The nasal passages were bilaterally patent without pathological secretions. The nasal septum was positioned medially without any features of hematoma. The frontal sinus was rinsed with a solution of octenisept, with the washes being clean and revealing no debris. In the following days gradual regression of the right eyelid and soft tissue edema was observed. The antibiotic therapy was also modified (clindamycin $300 \mathrm{mg}$ three times a day was replaced with metronidazole $500 \mathrm{mg}$ three times a day).

On the second day, due to hallucinations, confusion regarding time and place, verbal threats, and physical aggression towards the hospital staff, direct coercion was applied in the form of isolation and four-point restraint. The patient had a history of chronic alcohol abuse so he also had a psychiatric consultation (Agnieszka Wilk, MD, Medical University in Lodz). Direct coercion was continued until the delirium regressed, and tranquilizers were administered (hydroxyzinum) as well as antipsychotics (ketrel) and haloperidol as needed.

In the following days, the craniofacial wound healed normally with wound toilet performed at least twice a day. The frontal sinus was rinsed through the drain with a solution of octanisept and metronidazole. In spite of this, increasing C-reactive protein (CRP) values were observed: $29 \mathrm{mg} / \mathrm{L}$ on the day of admission, $79 \mathrm{mg} / \mathrm{L}$ on day two, and $120 \mathrm{mg} / \mathrm{L}$ on day 4 . Culture samples were collected from the right nasal cavity and right frontal sinus and antibiotic therapy was again modified (biofuroxime $750 \mathrm{mg}$ three times a day was replaced with meronem $500 \mathrm{mg}$ three times a day). CRP values decreased in subsequent days: $120 \mathrm{mg} / \mathrm{L}$ on the $4^{\text {th }}$ day, $85 \mathrm{mg} / \mathrm{L}$ on the $5^{\text {th }}$ day, and $23 \mathrm{mg} / \mathrm{L}$ on the day of discharge.

Staphylococcus epidermidis, which was grown from the collected culture samples, was susceptible to this antibiotic therapy. Improvement in the general condition of the patient was also observed: the patient was periodically logical and oriented about time and place; his general condition was good. On the 6th day, direct coercion was withdrawn.

On the $5^{\text {th }}$ day the patient had a maxillofacial consultation for possible additional surgery. A further CT scan showed a nasal fracture with dislocation, trauma of the right frontal sinus wall through the supraorbital margin and frontal process of the right maxilla, with an extensive surgically repaired wound extending from the nasal wing and lateral surface of the nose through the region of the eye angle to the forehead. Injuries did not involve the medial angle of the right eye (eyelid commissure). The patient did not experience diplopia when looking in various directions, and motility of the right eyeball was preserved with no lacrimation occurring. The fracture in the orbital roof seen on the CT film was not judged to require surgical intervention. Removal of the drain from the frontal sinus and restoration of the nasal cavity ventilation (FESS) was suggested. In the case of lacrimal duct obstruction, reconstruction would be necessary (Prof. Marcin Kozakiewicz, MD, PhD, Department of Maxillofacial and Reconstructive Surgery at the Medical University in Lodz).

On the 8th day the patient was in a good general condition, in logical-verbal contact, calm, and able to move independently within the room. He did not report any pain. There continued to be normal healing of the craniofacial wound with no signs of any inflammatory reaction. The sutures were removed leaving only single set (Fig. 4). The previous night, the patient himself removed the drain from the right frontal sinus. The drain was not reinserted. No pathological exudate and no swelling or pain was found at the site. An outer dressing was placed. Nasal packing with seton was also applied to promote healing; after removal, nasal patency was preserved, although slightly reduced on the right side due to a tendency to form synechia in the posterior-upper part. No pathological exudate or bleeding was observed. There was regression of the upper 
and lower eyelids with edema on the right side. While still severe this was clearly smaller compared to the previous days. Motility of both eyeballs was preserved.

The patient was discharged from the Department in good postoperative condition on the 9th day of hospitalization, with indications for further antibiotic therapy with biofuroxime. A daily toilet of the craniofacial wound was to continue, while taking the drugs (hydroxyzinum, ketrel) recommended by the consultant psychiatrist and further treatment in the Addiction Therapy Department. A follow-up appointment at the Department was established but the patient failed to attend.

\section{Discussion}

In the epidemiology of craniofacial injuries, accidents occurring while working with a circular saw account for $3.2 \%$ of all cases [13]. They mainly concern young people. Most often they result from lack of caution and experience and lack of skill in using the device, but also from operating it after alcohol consumption $[2,3,14]$. Rotating machines, including circular saws, are now widely available and frequently used both in households and in industrial plants. Craniofacial injuries caused by rotating devices are particularly dangerous and can often be life threatening. Rapid jerking of the circular saw can cause severe injuries, not only in the soft tissues and bones, but additionally can lead to foreign body fragments being left in the body and to massive hemorrhage due to damage of blood vessels. Involvement of the eyeball can naturally result in blindness [15]

The range and type of facial skeleton injuries vary widely. Based on data available in the literature [1,3,17-19], it is estimated that, in patients with craniofacial trauma, soft tissue injuries affect $52-66.3 \%$, nasal bone fractures account for $16.2-65 \%$, orbital walls $29.2 \%$, jaw $23.5 \%$, mandible $10.2 \%$, and frontal sinuses $5-12 \%$ [8-16].

In the patient presented here, the fracture of the anterior wall of the frontal sinus (with dislocation of fragments towards the piriform aperture on the right side) and the hematoma of the right frontal and maxillary sinus, were diagnosed on the basis of a CT scan. A CT scan is the basic test used in the diagnosis of craniofacial injuries. It allows assessment of craniofacial skeletal fractures, excludes the presence of foreign bodies, and can evaluate the status of the brain. In the case of suspected damage to large blood vessels CT angiography should also be performed [20,21]. If orbital foreign bodies are suspected, additional ultrasonographic examination is recommended $[22,23]$.

After diagnostic imaging, immediate surgical intervention is necessary. Wounds that are directly associated with bone fractures suggest intraoperative access to facilitate fusion of fragments. It is necessary to thoroughly debride wounds, remove foreign bodies and clots, and control bleeding with the possible sparing excision of wound margins [24]. Due to the wide variety of foreign bodies and the extent of injury, it is very important to assess the path of penetration of the foreign body. Its exact location and nature must be determined during diagnosis [20]. Appropriate drainage, wound debridement, and application of broad-spectrum antibiotic therapy play an important role in the prevention of post-traumatic complications.

The results of treatment for craniofacial injuries depend primarily on the extent and type of trauma sustained, as well as on the time elapsed from injury to the initiation of treatment. Severe life-threatening craniofacial injuries present very serious diagnostic and therapeutic problems [20]. They require rapid diagnostics and implementation of appropriate treatment, often multidisciplinary in nature.

The diagnostic and therapeutic management was successful in this case. The patient was discharged from hospital on the 9th day in good general condition. The external appearance after treatment was fully satisfactory for the patient. During the patient's stay at the department, there were no inflammatory complications in the healing of posttraumatic wounds. There was also no evidence of lagophthalmos, facial nerve paresis, ocular complications, or excessive lacrimation which could result from nosolacrimal duct obstruction. The therapeutic success, both functional and aesthetic, was achieved due to rapid diagnosis and the delivery of appropriate surgical and pharmacological treatment, including broad-spectrum antibiotic therapy.

\section{Conclusion}

In the case of extensive craniofacial injuries, rapid diagnosis and implementation of appropriate, highly specialized multidisciplinary treatment play a key role. Thus, patients such as the one described here should be referred to the highest-level medical centers.

\section{References}

1. Zielińska-Bliźniewska H, Niewiadomski P, Foczpański J, Pietkiewicz P, Olszewski J. Analiza obrażeń twarzoczaszki w materiale własnym. Kwart Ortop, 2012; 1: 135-40.

2. Gassner R, Tuli T, Hachl O, Rudisch A, Ulmer H. Craniomaxillofacial trauma: a 10 year review of 9543 cases with 21067 injuries. Craniomaxillofac Surg, 2003; 31(1): 51-61.

3. Brasileiro BF, Passeri LA. Epidemiological analysis of maxillofacial fractures in Brazil: a 5-year prospective study. Oral Surg Oral Med Oral Pathol. Oral Radiol Endod, 2006; 102(1): 28-34.

4. Jin KS, Lee H, Sohn JB, Han YS, Yung DU, Sim HY, Kim HS. Fracture patterns and causes in the craniofacial region: an 8-year review of 2076 patients. Maxillofac Plast Reconstr Surg, 2018; 40(1): 29.
5. Arangio P, Vellone V, Torre U, Calafati V, Capriotti M, Cascone P. Maxillofacial fractures in the province of Latina, Lazio, Italy: review of 400 injuries and 83 cases. J Craniomaxillofac Surg, 2014; 42(5): 583-7.

6. Lewandowski B, Brodowski R. Obrażenia czaszki twarzowej powstałe w czasie pracy piłą tarczową typu Kreisega. Fam Med Prim Care Rev, 2007; 9: 991-7.

7. Lewandowski B, Kluz B, Lech H, Pomianek J. Obrażenia czaszki twarzowej powstałe w wyniku pęknięcia tarczy piły tarczowej. Czas Stomatol, 1994; 47: 423-6. 
8. Hubert E, Szrmach J, Grabowska S, Piotrowski L, Preferansow J. Przyczyny i następstwa urazów części twarzowej czaszki powstałych na skutek wypadków w pracy w makroregionie północno-wschodnim. Med Pr, 1995; 46: 247-54.

9. Wesołowski P, Tokarska P, Mańka-Malara K, Wojtowicz A. Analiza rodzaju urazów doznawanych w obrębie twarzoczaszki w różnych dyscyplinach walki sportowej. Nowa Stomatol, 2012; 3: 108-13.

10. Franguelli A, Ruscito P, Bicciolo G. Head and neck trauma in sporting activities. J Craniomaxilofac Surg, 1991; 19(4): 178-81.

11. Reymond J, Podsiadło M, Kępa A, Wyskiel M. Foreign bodies in the orbit: report of three cases. Czas Stomatol, 2006; 59: 446-50.

12. Bubiłek-Bogacz A, Engelking-Adamczyk E, Waśkowska J. Foreign bodies in cheek: case report. Dent Med Probl, 2005; 42(3): 525-7.

13. Drozd M. Badanie przyczyn i następstw urazów głowy i szyi powstałych podczas pracy piłą tarczową. Otolaryngol Pol, 1992; 46: 316-8.

14. Pogorzelska-Stronczak B, Pelc R, Cieślik T, Waśkowski J. Skutki obrażeń czaszki twarzowej doznanych w czasie obsługi urządzeń z elementami wirującymi. Obserwacje kliniczne. Czas Stomatol, 1998; 51: 257-61.

15. Woytoń-Górawska H, Nienartwoicz J, Komorski J, Zawiślak E, Ziemski P. Urazy twarzoczaszki powstałe podczas pracy z narzędziami wirującymi: opis dwóch przypadków. Ostry Dyżur, 2014; 7(1): 33-6.

16. Park KP, Lim SU, Kim JH, Chun WB, Shin DW, Kim JY, Lee H. Fracture patterns in the maxillofacial region: a four-year retrospective study. J Korean Assoc Oral Maxillofac Surg, 2015; 41(6): 306-16.
17. Kraft A, Abermann E, Stigler R, Zsifkovits C, Pedross F, Kloss F, Gassner R. Craniomaxillofacial trauma: synopsis of 14,654 cases with 35,129 Injuries in 15 years. Craniomaxillofac Trauma Reconstr, 2012; 5(1): 41-50.

18. Xie C, Mehendale N, Barrett D, Bui CJ, Metzinger SE. 30-year retrospective review of frontal sinus fractures: the Charity Hospital experience. J Craniomaxillofac Trauma, 2000; 6: 7-15.

19. Manolidis S, Hollier LH. Management of frontal sinus fractures. Plast Reconstr Surg, 2007; 120(7 Suppl 2): 32-48.

20. Olszewski J, Kozakiewicz M, Hilt T, Sut M, Repetowski M, Urbaniak J. Ciężki uraz okolicy twarzoczaszki i szyi połączony z wniknięciem ciał obcych podczas obróbki drewna. Otolaryngol Pol, 2013; 67: 45-51.

21. Kassel EE, Noyek AM, Cooper PW. CT in facial trauma. J Otolaryngol, 1983: 12(1): 2-15.

22. Neuman K, Ehrich D, Bloching M. Orbital foreign bodies: diagnostics, therapy and management. Laryngorhinootol 2005;84:187-92.

23. Rubinstein A, Riddel CE, Kafil-Hussain A, Assaf A. Self-inserted intraorbital foreign bodies. Ophthal Plast Reconstr Surg, 2005; 21: 156-7.

24. Khurram SA, Atkins S, Smith KG, Yates JM. A multidisciplinary approach to management of extensive facial injuries resulting from the use an angle grinder. Injury Extra, 2011; 42: 75-8. 